\title{
IR-SPECTROSCOPY AND AFM-MICROSCOPY OF THE SURFACE OF GAMMA-IRRADIATED GaS AND GaS:Yb LAYERED SINGLE CRYSTALS
}

\author{
A.M. Pashayev ${ }^{1}$, B.G. Tagiyev ${ }^{1}$, R.S. Madatov ${ }^{1,2}$, N.N. Gadzhieva ${ }^{2}$, A.A. Aliev ${ }^{1}$, F.G. Asadov ${ }^{2}$ \\ ${ }^{1}$ National Aviation Academy of Azerbaijan, \\ AZ1045, Baku, Azerbaijan; \\ ${ }^{2}$ Institute of Radiation Problems National Academy of Sciences of Azerbaijan, \\ AZ1143, Baku, Azerbaijan \\ E-mail:nushaba6@mail.ru
}

For the first time, information on the surface relief of the layered $\mathrm{GaS}$ and doped $\mathrm{GaS}: \mathrm{Yb}$ single crystals subjected to gamma-irradiation was obtained using atomic force microscopy (AFM) and Fourier-transform infrared spectroscopy (FTIR). It was found that GaS is characterized by a non-uniform distribution of irregularities with different heights and periodicities, and when doping crystals with $\mathrm{Yb}$ atoms, the distribution of irregularities becomes more orderly, the height and periodicity of irregularities decreases. In the FTIR spectra, changes in the reflection coefficients of the surface of $\mathrm{GaS}$ and $\mathrm{GaS}: \mathrm{Yb}$ single crystals are observed as a function of the gammairradiation dose $\left(\Phi_{\gamma}=30 \ldots 200 \mathrm{krad}\right)$, and on the basis of spectroscopic and microscopic changes, it was found that doped single crystals are the most radiation-resistant.

PACS: 78.30.Fs; 61.80.Ed; 61.82.Fk

\section{INTRODUCTION}

Layered $\mathrm{A}^{3} \mathrm{~B}^{6}$ semiconductors, in particular, gallium sulfide single crystals $(\mathrm{GaS})$ are promising materials for radiation detectors of various types. On the basis of these single crystals, radiation detectors of gammaquanta operating at room temperature [1-5] are fabricated. The increased interest in these compounds is due to the anisotropy of their crystalline structure, which allows obtaining perfect faces with a sufficiently low density of surface states, which is important for obtaining high quality heterojunctions.

One of the effective methods for changing the surface of layered gallium sulfide single crystals is to irradiate it with $\gamma$-quanta [2-6]. The depth of penetration of gamma-quanta is comparable to the value of the inverse light absorption coefficient $\left(\sim 10^{2} \mathrm{~nm}\right)$, which leads to the desorption of gases from the surface and recharging the surface active centers. This factor is decisive in many processes occurring near the surface of the crystal. Therefore, studying the effect of external influences, including gamma-radiation, on the edge photoconductivity (FC) of a defective semiconductor, one can establish the role of surface heterogeneity and roughness during its formation [4]. The most informative methods for studying the surface of semiconductors are the methods of FTIR and AFM $[7,8]$.

Based on these considerations, the present work presents the results of AFM and FTIR studies of changes in the surface relief of gamma-irradiated layered $\mathrm{GaS}$ and $\mathrm{GaS}: \mathrm{Yb}$ single crystals.

\section{EXPERIMENTAL TECHNIQUE}

Single crystals of $\mathrm{p}-\mathrm{GaS}$ were grown by the method of directional solidification of the melt (vertical version of the Bridgman method). When growing GaS, an excess of sulfur $(1.5 \%)$ was used to determine the possibility of filling vacancies with sulfur atoms. The resistivity of the samples obtained along and perpendicular to the $\mathrm{C}$ axis at room temperature was
$3 \cdot 10^{7}$ and $2 \cdot 10^{9} \Omega \cdot \mathrm{cm}$, respectively. Doping of $\mathrm{Yb}$ was carried out in the process of crystal growth, and the concentration of $\mathrm{Yb}$ in crystals was $\mathrm{N}_{\mathrm{Yb}} \sim 10^{18} \mathrm{~cm}^{-3}$. Indium, which was smelted on the surface of gallium sulfide at a temperature of $150{ }^{\circ} \mathrm{C}$, was used as the ohmic contacts. Microstructural and X-ray phase analyzes showed that the obtained crystals were homogeneous and did not contain crystalline inclusions $[2,3]$.

The Fourier transform infrared reflection spectra of the samples were recorded on a Varian 3600 FTIR spectrometer in the frequency range $v=400 \ldots 100 \mathrm{~cm}^{-1}$ at room temperature. The reflection spectra were obtained at an angle of incidence $\varphi=15^{\circ}$.

Microscopic studies of the surface relief of the initial gamma-irradiated $\mathrm{GaS}$ and $\mathrm{GaS}: \mathrm{Yb}$ samples were carried out with an AFM. For this purpose, twodimensional (2D) and three-dimensional (3D) surface AFM images were obtained, as well as histograms (distribution curves of surface images on the size of irregularities) in the horizontal and vertical directions. Samples were irradiated with gamma-quanta from a ${ }^{60} \mathrm{Co}$ source at room temperature with a dose rate $\mathrm{d} \Phi_{\gamma} / \mathrm{d} t=15.66 \mathrm{rad} / \mathrm{s}$. The samples were irradiated with doses of 30, 50, 100, 140, and $200 \mathrm{krad}[6,9]$.

\section{RESULTS AND ITS DISCUSSION}

IR reflection spectra in the region of lattice oscillations of the initial (1) and irradiated doses of $\Phi_{\gamma}=140$ (2) and $200 \mathrm{krad}$ (3) of $\mathrm{GaS}$ and $\mathrm{GaS}: \mathrm{Yb}$ single crystals are shown in Fig. 1. As seen from Fig. 1,a (curve 1), in the reflection spectra transverse $v_{\mathrm{TO}}=315.3 \mathrm{~cm}^{-1}$ and longitudinal $v_{\mathrm{LO}}=365.6 \mathrm{~cm}^{-1}$ oscillations, which converge to classical dispersive analysis, are observed in the original GaS. Gammairradiation of $\mathrm{GaS}$ samples with doses of 140 and $200 \mathrm{krad}$ slightly changes (distorts) the lattice reflection spectra (curves 2 and 3). With an increase in the gamma-irradiation dose, the value of the reflection coefficient decreases, and the region of residual rays 
deepens. The observed feature in the band of residual $\mathrm{GaS}$ rays that appears in the irradiated samples can presumably be explained by a change in the surface

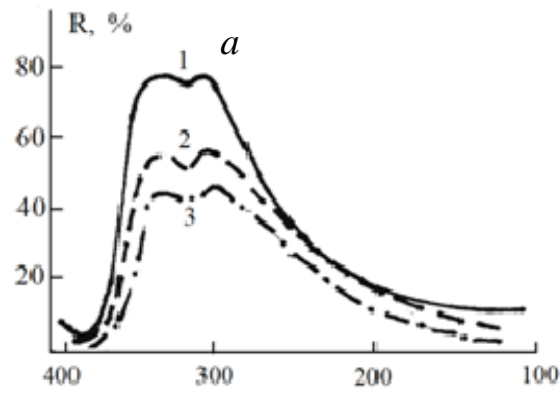

state under the action of gamma-radiation and the formation of quasi-phonons, which lie in the region of residual rays [10].

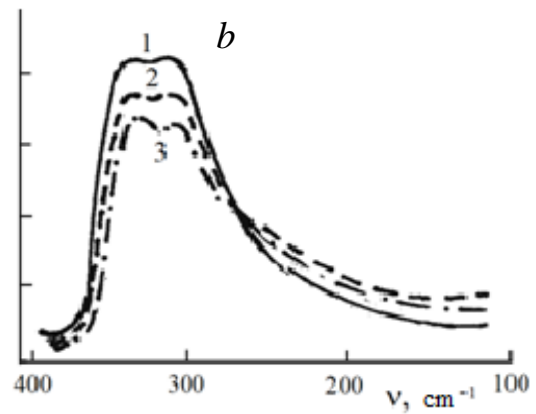

Fig. 1. FTIR spectra of the original, non-irradiated (1), and irradiated with doses of $\Phi_{\gamma}=140$ (2) and $200 \mathrm{krad}(3)$ of GaS (a) and GaS:Yb (b) single crystals

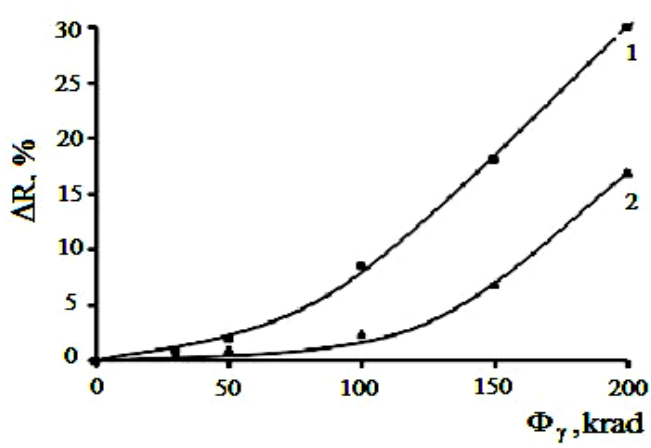

Fig. 1,b shows the reflection spectra of the initial (curve 1) and irradiated doses of 140 and $200 \mathrm{krad}$ (curves 2 and 3) of the GaS: Yb samples. As can be seen from Fig. 1,b, the doping of gallium sulfide with ytterbium actually does not affect the values of the frequencies of longitudinal and transverse oscillations. However, the surface state improves and is accompanied by an increase in the reflection coefficient (albedo) by $R \sim 5 \ldots 8 \%$. Gamma-irradiation of $\mathrm{GaS}: \mathrm{Yb}$ samples with doses of 140 and $200 \mathrm{krad}$ leads to a deterioration of the surface state, since $\mathrm{R}$ values with increasing absorbed radiation dose are decreasing. Fig. 2 presents the changes in the values of the difference of the reflection coefficient $\Delta R=R_{0}-R$ (where $\mathrm{R}_{0}$ and $\mathrm{R}$ are the reflection coefficients of the original and gamma-irradiated samples, respectively) depending on the absorbed gamma-irradiation dose for the GaS (curve 1) and GaS: Yb samples (curve 2). A comparative analysis of these dependencies reveals the following:

1. Both dependencies are close to a parabolic law.

2. The growth rate of the difference $\Delta R$ determined in the linear regions of dependences in the case of gamma-irradiated $\mathrm{GaS}$ samples is $\sim 1.5$ times higher than the growth rate of the $\Delta R$ value in the case of gamma -irradiated GaS: Yb samples.

3. The sharp increse in the difference $\Delta R$ occur for GaS samples with an absorbed dose of $\Phi_{\gamma} \geq 50 \mathrm{krad}$, and for GaS:Yb samples at $\Phi_{\gamma} \geq 140 \mathrm{krad}$.

The observed features of the curves of $\Delta R$ versus $\Phi_{\gamma}$ for $\mathrm{GaS}$ and $\mathrm{GaS}: \mathrm{Yb}$ samples show that the gallium sulfide surface is more sensitive to gamma-ray effects than gallium sulfide surface doped with ytterbium. In this case, the effect of gamma-quanta causes the heterogeneity and roughness of the surface and,
Fig. 2. Changes of the values of the difference of the reflection coefficient $(\Delta R)$ depending on the absorbed dose of gamma-irradiation for GaS (1) and GaS:Yb (2) single crystals

consequently, leads to its deterioration in these layered single crystals.

The obtained results are in good agreement with the results of [5], according to which, $\mathrm{GaS}$ and $\mathrm{GaS}: \mathrm{Yb}$ single crystals with values of $\Phi_{\gamma} \leq 140 \mathrm{krad}$ are radiation-resistant, and above these values of absorbed doses, respectively, are not radiation-resistant.

Changes in the surface relief of layered $\mathrm{GaS}$ and $\mathrm{GaS}: \mathrm{Yb}$ single crystals caused by gamma-quanta were also traced by the microscopic (AFM) method. As an example, Fig. 3 shows three-dimensional (3d) images of the surface of the original (see Fig. 3,a,b) and gammairradiated with $140 \mathrm{krad}$ (see Fig. 3,c,d) samples of GaS and $\mathrm{GaS}: \mathrm{Yb}$, respectively. Comparison of the surfaces of the initial single crystals shows that if the surface of gallium sulfide is characterized by the presence of subroughness and heterogeneity, the introduction of ytterbium impurity into the GaS structure leads to a smoothing and uniformity of its surface. In this case, the depth of irregularities in the case of $\mathrm{GaS}: \mathrm{Yb}$ decreases by a factor of $\sim 5$ (from 8 to $40 \mathrm{~nm}$ ) compared to GaS.

Irradiation of $\mathrm{GaS}$ and $\mathrm{GaS}: \mathrm{Yb}$ single crystals with a dose of $140 \mathrm{krad}$ is accompanied by a change in the surface state of these samples. After irradiation with gamma-rays with a dose of $140 \mathrm{krad}$, the surface state of GaS deteriorates significantly, while minor changes occur on the GaS: $\mathrm{Yb}$ surface. Annealing the samples at a temperature of $t=100{ }^{\circ} \mathrm{C}$ for 1 hour partially restores the surface of the irradiated samples. It should be noted that the analysis of 3D images of surfaces of $\gamma$-irradiated $\mathrm{GaS}$ and $\mathrm{GaS}: \mathrm{Yb}$ samples with doses of $30,50,100,140$, and $200 \mathrm{krad}$ allows us to conclude that the boundary values of the dose of surface changes are 50 and $140 \mathrm{krad}$, respectively. 

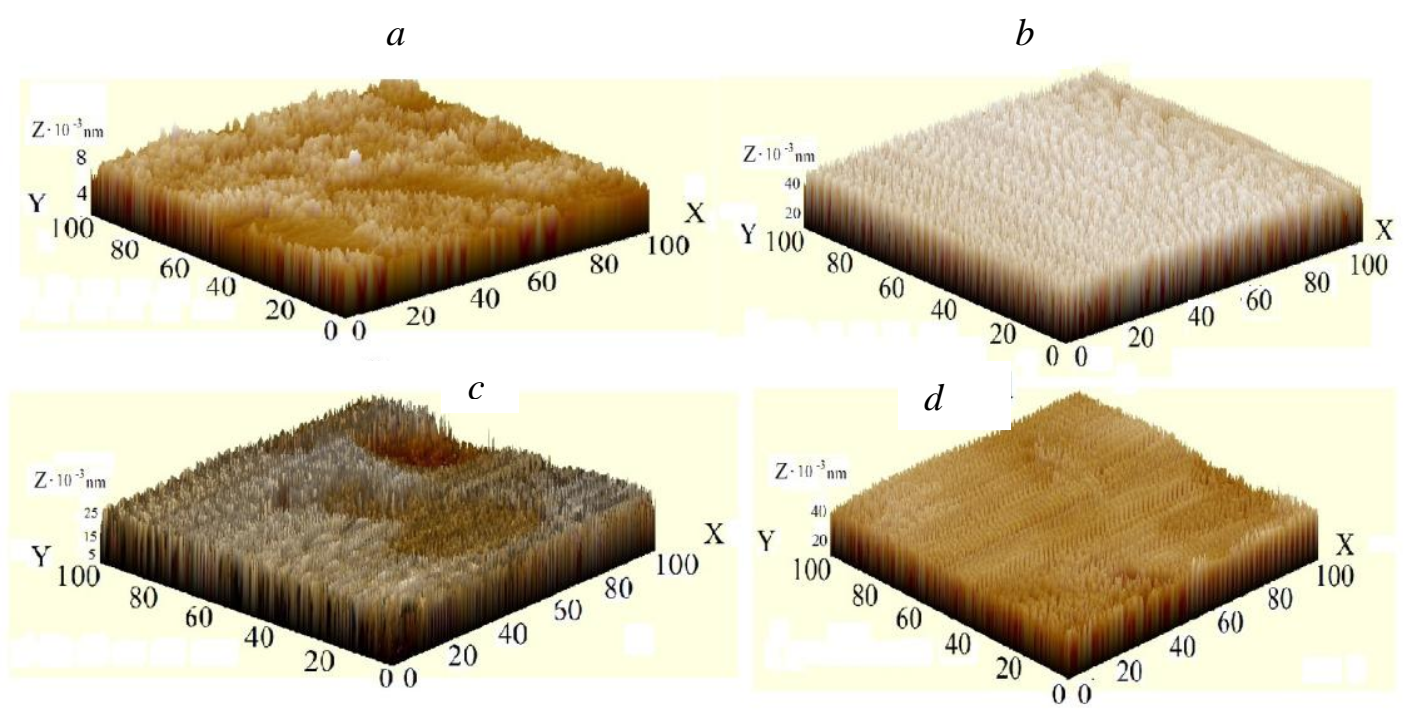

Fig. 3. Three-dimensional images of the surface of the original $(a, b)$ and $\gamma$-irradiated dose with of $140 \mathrm{krad}(c, d)$ of $G a S(a, c)$ and $G a S: Y b(b, d)$ single crystals

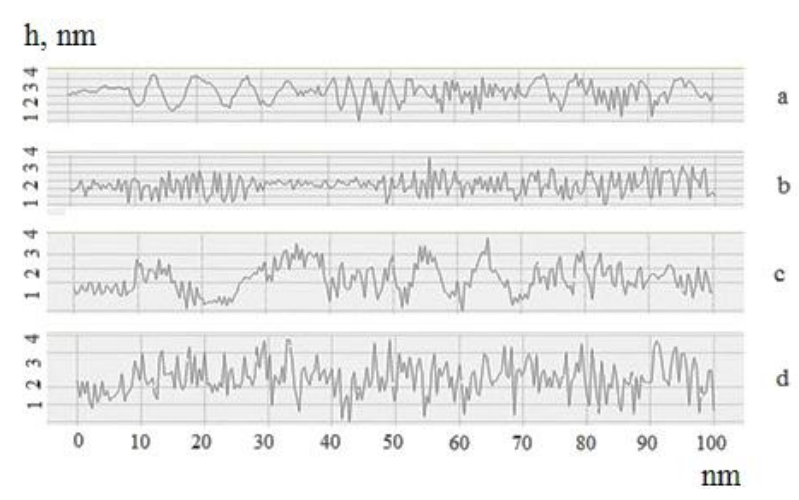

Fig. 4. Histograms of $2 d$ images of the initial $(a, b)$ and $\gamma$-irradiated doses of $140 \mathrm{krad}(\mathrm{c}, \mathrm{d})$ of GaS single crystals in horizontal $(a, c)$ and vertical $(b, d)$ directions

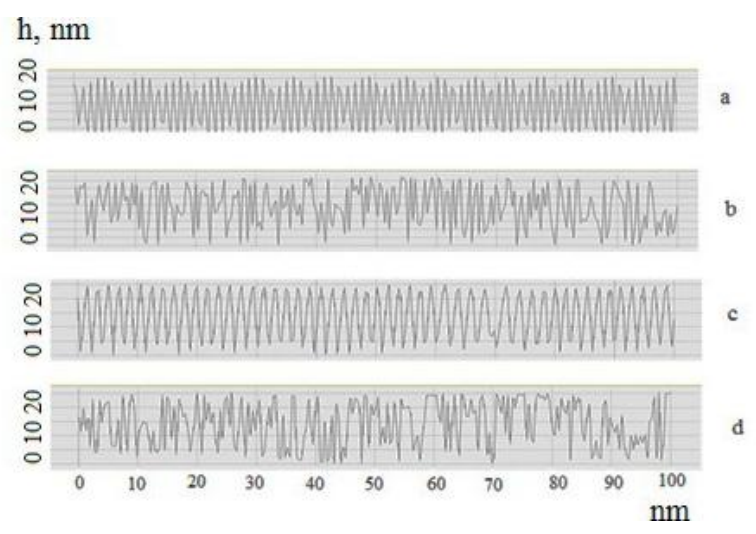

Fig. 5. Histograms of $2 d$ images of the initial $(a, b)$ and $\gamma$-irradiated dose of $140 \mathrm{krad}(c, d) \mathrm{GaS}: \mathrm{Yb}$ single crystals in the horizontal $(a, c)$ and vertical $(b, d)$ directions

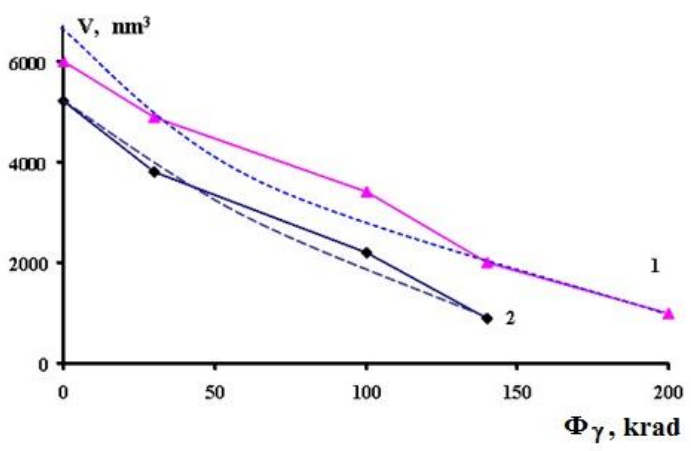

Figs. 4 and 5 show the histograms of 2D images (curves of the distribution of surface images by the size of irregularities) in the horizontal and vertical directions of the selected section $(100 \times 100 \mathrm{~nm})$. As can be seen from the histograms, the $\mathrm{GaS}$ single crystal is characterized by an uneven distribution of irregularities, both in the horizontal and in the vertical directions with different heights of $\sim 30 \ldots 40 \mathrm{~nm}$ and a frequency of
Fig. 6. Dose dependences of the free volume of irregularities in GaS (1) and GaS:Yb (2) single crystals.

(Dashed lines show exponential approximating (regression) dependences)

$\sim 16 \mathrm{~nm}$ (see Fig. 4,a,b). GaS:Yb single crystal histograms show a uniform distribution of irregularities in both horizontal and vertical directions with the same height of $\sim 25 \mathrm{~nm}$ and a frequency of $\sim 13 \mathrm{~nm}$ (see Fig. 5,a and b). Irradiation with a dose of $140 \mathrm{krad}$ of these samples leads to a strong (see Fig. 4,c,d) and minor (see Fig. 5,c,d) changes in histograms for GaS and $\mathrm{GaS}: \mathrm{Yb}$, respectively. 
Considering the sub-roughness profile in the framework of multifractal analysis, we can assume that it has the invariance property when the same unit free volume (straight cone of height $h$ and diameter $d$ ) is continuously repeated over the entire area $[8,9]$.

The dose dependence of a single free volume of irregularities (a single average volume of a reliefforming cone), which is shown in Fig. 6, was studied. The dependence is exponential: $V=A \cdot e^{k x}$ ( $V$ is a single average volume of a relief-forming cone, $A$ is a single crystal constant, $k$ is an absorption coefficient, $x$ is the irradiation dose). As can be seen from Fig. 6, with an increase in the gamma-irradiation dose to $140 \mathrm{krad}$, the value of a single average volume of the relief-forming cone $V$ decreases by $\sim 2.5 \ldots .5$ times (from 6000 and 5500 to 2500 and $1000 \mathrm{~nm}^{3}$ ) for $\mathrm{GaS}$ and $\mathrm{GaS}: \mathrm{Yb}$, respectively.

\section{CONCLUSIONS}

The surface relief of undoped $\mathrm{GaS}$ and doped $\mathrm{GaS}: \mathrm{Yb}$ single crystals subjected to gamma-irradiation was studied by AFM and FTIR. It was found that $\mathrm{GaS}$ is characterized by an uneven distribution of irregularities with different heights $\sim 30 \ldots 40 \mathrm{~nm}$ and a frequency of $\sim 16 \mathrm{~nm}$ subjected to gamma-irradiation. When doping crystals with $\mathrm{Yb}$ atoms, the distribution of irregularities becomes more orderly, the height is $\sim 25 \mathrm{~nm}$, and the periodicity of $\sim 13 \mathrm{~nm}$ irregularities decrease. In the FTIR spectra, changes in the reflection coefficients of the surface of $\mathrm{GaS}$ and $\mathrm{GaS}: \mathrm{Yb}$ single crystals are observed as a function of the gamma-irradiation dose $\left(\Phi_{\gamma}=30 \ldots 200 \mathrm{krad}\right)$, and on the basis of these changes, it was found that doped single crystals are the most radiation-resistant.

The use of a single average volume of a reliefforming cone was introduced as a characteristic of the development of the surface of layered crystals. Regression dependencies of the effect of the degree of irradiation on a single average volume of the reliefforming cone are proposed, expressed in the exponential form $V=A \cdot e^{k x}$. The dependence was established between the distribution profile of a single free volume of irregularities (a single average volume of a reliefforming cone), obtained by AFM and the radiation resistance of layered $\mathrm{GaS}$ : $\mathrm{Yb}$ single crystals.

In order to explain the experimental facts established by us, we propose the following physical model of the processes occurring during the accumulation of clusters of defects consisting of $\mathrm{V}_{\mathrm{Ga}}$ and $\mathrm{Ga}_{\mathrm{i}}$ in the form of a cone in grown crystals. When pure and impurity GaS single crystals are irradiated with $E \approx 1.2 \mathrm{MeV}$ and a low dose of $30 \ldots 200 \mathrm{krad}$, apparently due to radiationstimulated annealing of defects, the clusters of defects decompose, releasing $\mathrm{V}_{\mathrm{Ga}}$ (of which the cluster of defects consists) and $\mathrm{Ga}_{\mathrm{i}}$ which is located on the periphery of the defect clusters. In this regard, the volume of the periphery of the relief-forming cone decreases with increasing radiation dose and, as a result, the smoothing of defects on the surface of crystals occurs [11]. Thus, the dose adjustment of defects and the rate of change of free volume depending on the dose of radiation determines the radiation resistance of materials and does depend on the initial state of their surfaces.

\section{REFERENCES}

1. A.Z. Abasova, R.S. Madatov, V.I. Stafeev. Radiation-stimulated processes in chalcogenide structures. Baku: "ELM", 2011, 352 p.

2. R.S. Madatov, T.B. Tagiyev, A.I. Najafov, et al. Optical and photoelectrical properties of lamellar gallium sulfide single crystals irradiated by $\gamma$-quanta // Semicond. Phys. Quantum Electronics Optoelectronics. 2006, v. 9, N 2, p. 8-11.

3. R.S. Madatov, A.I. Najafov, T.B. Tagiyev, Sh.P. Shekily. Optical and photoelectric properties of layered GaS: $\mathrm{Er}^{3+} / /$ Inorganic materials. 2008, v. 44, N 4, p. 396-399.

4. A.A. Garibov, R.S. Madatov, Y.F. Mustafaev, et al. Structural and optical properties of GaS Single crystals irradiated by hydrogen // Journal of Electronic Materials, DOI: 10.1007/s11664-015-3904-4, The Minerals, Metals Materials Society, 2015.

5. R.S. Madatov, N.N. Gadzhieva, A.I. Najafov, et al. Radiation Effect on Layered Crystals $\mathrm{GaS}$ and GaS:Yb // Colloid and Surface Science. 2017, v. 2, N 1, p. 43-46.

6. A.K. Pikaev. Dosimetry in Radiation Chemistry. M.: "Nauka", 1975, 311 p.

7. R.S. Madatov, N.N. Gadzhieva, F.G. Asadova, Z.I. Asadova. Radiation Modification of the Structure of Layer Crystals of Sulfide Gallium // Problems of Atomic Science and Technology. 2018, N 5(117), p. 116-120.

8. Yu.S. Nagornov, I.S. Yasnikov, M.N. Turkov. Togliatti research methods; TSU. 2012, 58 p.

9. M.L. Zanavezkin. Atomic force microscopy in the study of the roughness of nanostructured surfaces // Abstract on the Search for Physical and Mathematical Sciences. M., 2008, 26 p.

10. K.R. Allahverdiyev. Optical properties and vibrational spectra of layered and chain $A^{3} B^{6}, A^{3} B^{3} C^{26}$ crystals and solid solutions based on them: Dis. doc. phys. sciences. Baku, 1980, 313 p.

11. V.I. Bespalov. Interaction of ionizing radiation with matter. Tomsk: "Hang Glider", 2006, 368 p.

Article received 11.01.2019

\section{ИК-СПЕКТРОСКОПИЯ И АСМ-МИКРОСКОПИЯ ПОВЕРХНОСТИ ГАММА-ОБЛУЧЕННЫХ СЛОИСТЫХ МОНОКРИСТАЛЛОВ GaS И GaS:Yb}

\section{А.М. Пачаев, Б.Г. Тагиев, Р.С. Мадатов, Н.Н. Гаджиева, А.А. Алиев, Ф.Г. Асадов}

Впервые методами атомно-силовой микроскопии (ACM) и ИК-фурье-спектроскопии получена информация о рельефе поверхности нелегированных $\mathrm{GaS}$ и легированных монокристаллов GaS:Yb, 
подвергнутых гамма-облучению. Установлено, что для монокристаллов GaS характерно неравномерное распределение неровностей с различной высотой и периодичностью, а при легировании кристаллов атомами $\mathrm{Yb}$ распределение неровностей упорядочится, их высота и периодичность уменьшатся. В ИК-фурьеспектрах наблюдаются изменения коэффициентов отражения поверхности монокристаллов $\mathrm{GaS}$ и $\mathrm{GaS}: \mathrm{Yb}$ в зависимости от дозы гамма-облучения $\left(\Phi_{\gamma}=30 \ldots 200\right.$ крад), и на основе этих изменений установлено, что легированные монокристаллы являются более радиационно стойкими.

\title{
ІК-СПЕКТРОСКОПІЯ І АСМ-МІКРОСКОПІЯ ПОВЕРХНІ ГАММА-ОПРОМІНЕНИХ ШАРУВАТИХ МОНОКРИСТАЛІВ GaS I GaS:Yb
}

\author{
А.М. Пашаєв, Б.Г. Тагієв, Р.С. Мадатов, М.М. Гаджиєва, А.А. Алієв, Ф.Г. Асадов
}

Вперше методами атомно-силової мікроскопії (ACM) і IК-фур'є-спектроскопії отримано інформацію про рельєф поверхні нелегованих GaS i легованих монокристалів GaS:Yb, підданих гамма-опроміненню. Встановлено, що для монокристалів $\mathrm{GaS}$ характерний нерівномірний розподіл нерівностей з різною висотою i періодичністю, а при легуванні кристалів атомами Yb розподіл нерівностей упорядкується, їх висота $\mathrm{i}$ періодичність зменшаться. В ІК-фур'є-спектрах спостерігаються зміни коефіцієнтів відбиття поверхні монокристалів $\mathrm{GaS}$ i GaS:Yb в залежності від дози гамма-опромінення ( $\Phi \gamma=30 \ldots 200$ крад), і на основі цих змін встановлено, що леговані монокристали є більш радіаційно стійкими. 